\title{
Hybrid RNC-isolation of Structures Under Near-fault Earthquakes
}

\author{
Mohammed Ismail, Francesc Pozo and José Rodellar
}

\begin{abstract}
The problem of combining active damping with a purely passive isolation system, with hysteretic damping, to reduce possible pounding effects under near-fault ground motions is addressed. The used isolation system is a recently proposed one that is referred to as roll in cage (RNC) isolator. It has an integrated buffer mechanism to prevent excessive bearing displacements under strong seismic excitations. Therefore, possible pounding under such strong earthquakes will be within the bounds of RNC isolator to avoid adjacent structural pounding. Active control is invoked at a certain bearing displacement to reduce it before reaching its design limit, after which pounding takes place. It was found that increasing the RNC isolator's inherent hysteretic damping reduces the bearing displacement and consequently alleviates or even eliminate pounding. Moreover, the integration of active control, at smaller bearing displacements, with the RNC isolator can reduce the bearing displacement but adds more rigidity to the isolation system, which leads to less efficient isolation.
\end{abstract}

\section{INTRODUCTION}

Seismic isolation systems are essentially designed to preserve structural safety, prevent occupants injury and properties damage. The major concept in base isolation is to diminish the fundamental frequency of structural vibration to a value lower than the dominant energy frequencies of earthquake ground motions. However, seismically isolated structures are expected to experience large displacements relative to the ground especially under near-fault (NF) earthquakes. The NF ground motions are characterized by one or more intense long-period velocity and displacement pulses, which lead to a large isolator displacement [12], [18]. Such large displacements are accommodated by providing a sufficient seismic gap around the isolated structure. In some cases, the width of the provided seismic gap is limited due to practical constraints. Therefore, a reasonable concern is the possibility of pounding of a seismically isolated structures with the surrounding adjacent structures during severe seismic excitations such as NF ground motion

M. Ismail is an assistant professor, Structural Engineering Department, Zagazig University, 44519-Zagazig, Egypt. Post-doctoral researcher, Universitat Politècnica de Catalunya-BarcelonaTECH, EUETIB, C/ Comte d'Urgell 187 08036-Barcelona, Spain. mohammed.ismaileupc.edu

F. Pozo is an associate professor and is with CoDAlab, Departament de Matemàtica Aplicada III, Escola Universitària d'Enginyeria Tècnica Industrial de Barcelona, Universitat Politècnica de CatalunyaBarcelonaTECH, Comte d'Urgell, 187, 08036 Barcelona, Spain. francesc.pozo@upc.edu

J. Rodellar is a professor and is with CoDAlab, Departament de Matemàtica Aplicada III, ETSECCPB, Universitat Politècnica de Catalunya-BarcelonaTECH, Jordi Girona 1-3, 08034 Barcelona, Spain. jose.rodel lar@upc.edu

This work was supported by the Spanish Ministry of Science and Innovation project (DPI2011-28033-C03-01) earthquakes.

Compared to the extensive research work on pounding of conventional buildings and bridges, very limited research studies have been carried out for pounding of seismically isolated buildings [19]. [23] simulated the superstructure of an isolated building as a continuous shear beam in order to investigate the effects of pounding on structural response. A very high acceleration response was observed during pounding with the surrounding retaining wall at the isolation level. Similar work was done by [16] and it was found that the base shear forces increase with the stiffness of the isolated structure or the surrounding retaining wall. Pounding of seismically isolated structures considering different types of isolation systems was analytically investigated by [17]. They concluded that pounding effects are more significant if the isolated superstructure is flexible or the adjacent structures are stiff. Through parametric analysis, [14], [13] studied the effects of pounding of a seismically isolated building with the surrounding retaining wall, revealing the damaging effects of structural impact on the effectiveness of seismic isolation. Considering a sliding isolation system with varying friction, [4] investigated the earthquake induced upper story pounding response of two buildings in close proximity. They concluded that the impact force is very high when the sliding friction coefficient is constant, while it becomes quite low when the friction coefficient is allowed to vary with velocity.

The combination of passive base isolators and feedback controllers (applying forces to the base) has been proposed in recent years. Some researchers have proposed active feedback systems, for instance, [5]-[7]. More recently, semi-active controllers have been proposed in the same setting with the hope of gaining advantage from their easier implementation (see, for instance, [6], [22]). It is accepted that passive, semi-active and active control systems installed in parallel with base isolation bearings have the potential of reducing responses of base-isolated structures more significantly than classical passive dampers [25], [22].

In this paper, the possibility of pounding and its mitigation of seismically isolated buildings is investigated using a recently proposed isolation system, referred to as roll in cage (RNC) isolator [9], [11], [10], under NF ground motion, see Fig. 1. The RNC isolator provides in a single 


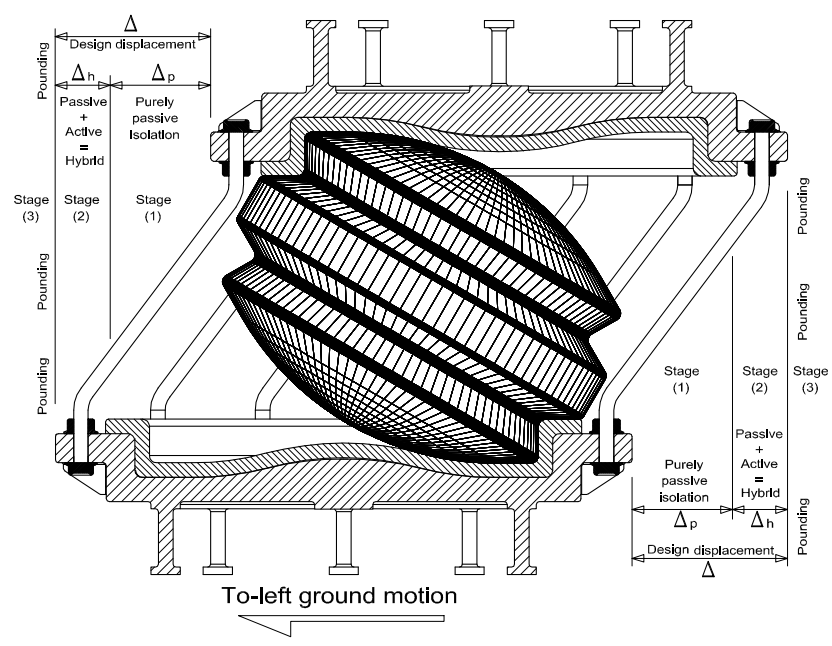

Fig. 2. The integrated buffer mechanism of the RNC isolator

unit all the necessary functions of rigid support, horizontal flexibility with enhanced stability and energy dissipation characteristics. It has an integrated buffer mechanism to prevent excessive bearing displacements under strong seismic excitations. This means that pounding would take place within the RNC isolator itself, after exceeding a certain predetermined design bearing displacement, under earthquakes stronger than the design earthquake, so that pounding of the isolated structures itself with the adjacent structures is avoided. Therefore, the very likely damage due to structural pounding during strong earthquakes could be minimized or even avoided.

The approach of reducing pounding in this research is twofold: first by investigating the ability of the provided RNC isolator damping, by means of metallic hysteretic dampers arranged around the rolling body as seen in Fig. 1, to limit the bearing displacement to be within affordable limits. Therefore, pounding may not take place. The second is by actively controlling, reducing, the isolated base displacement just before attaining the design bearing displacement, as demonstrated by Fig. 2. This reduces the possibility of pounding or at least alleviate the severity of shock within the bounds of the RNC isolator and its undesirable effects on the isolated superstructure.

\section{NEAR-FAULT GROUND MOTIONS}

$\mathrm{NF}$ ground motions are characterized by one or more intense long-period velocity and displacement pulses that can lead to a large isolator displacement [12], [18]. Therefore, five NF ground motions of different intensities and various velocity and displacement pulses are considered to assess the performance of the RNC isolator damping and buffer mechanisms. These NF ground motions were obtained from the near-most station to the fault rupture, with intensities that range from $0.27 \mathrm{~g}$ to $1.23 \mathrm{~g}$ to represent small to severe intensity earthquakes. The peak ground accelerations (PGA), velocities (PGV) and displacements (PGD) against their corresponding time instants of each ground motion are listed in Table I. On measuring the intensity of NF ground motions, [15] revealed that the peak ground acceleration is a better representative intensity measure than the peak ground velocity. Accordingly, the used NF ground motions are sorted by their PGA in an ascending order.

\section{MODELING OF ISOLATED STRUCTURE}

The RNC-isolated structure in this paper is a symmetric 3D building of 5 bays, each of $8.0 \mathrm{~m}$ span, with double end cantilevers, each of $2.5 \mathrm{~m}$ length, in each horizontal direction. It has 8 floors plus the isolated base floor with a typical story height of $3.0 \mathrm{~m}$. The base isolated structure is modeled as a shear type supported on 36 heavy-load RNC isolators, one under each column. Each floor has 2 lateral displacement degrees of freedom (DOF) beside one rotational DOF around the vertical axis. However, due to the symmetry of the 3D structure, only one horizontal displacement DOF is considered at each floor and is excited by a single horizontal component of earthquake ground motion in its direction. The superstructure is considered to remain within the elastic limit during the earthquake excitation and impact phenomenon. The construction material of the isolated structure is normalweight reinforced concrete with a total material volume of $4068.36 \mathrm{~m}^{3}$ and the structure has a total weight of 10170.90 tons. The fixed-base structure has a fundamental period of $0.436 \mathrm{sec}$ and modal frequencies of $2.29,6.80,11.06$, $14.94,18.29,21.02,23.03$ and $24.26 \mathrm{~Hz}$ for modes from one to eight, respectively. The structural damping ratio for all modes is fixed to $2.50 \%$ of the critical damping, see Fig. 4.

The RNC isolator has three main forms as shown in Fig. 1. In this study, the heavy loads form shown in Fig. 1 (c) is used to safely support the heavy column reactions. The designed RNC isolator for this study is $1.45 \mathrm{~m}$ high. The outer diameter of the upper and lower bearing steel plates is $2.73 \mathrm{~m}$. It is provided with 8 hysteretic mild steel dampers of the shape shown in Fig. 1, each has a diameters of $5.0 \mathrm{~cm}$. This RNC isolator design allows for a horizontal design displacement of $53.0 \mathrm{~cm}$, after which the integrated buffer stops the motion through impact within the lock mechanism shown in Fig. 2. As shown in Fig. 1(c), the heavy load form of the RNC isolator is provided with a hollow elastomeric cylinder around the rolling body to represent the main load carrying capacity, while the rolling body itself works as a secondary support in this case. The inner and outer diameters of the hollow elastomeric cylinder are $1.73 \mathrm{~m}$ and $2.33 \mathrm{~m}$, respectively. This elastomeric part was initially designed to follow some available recommendations of the Uniform Building Code [1] and AASHTO [2]. At the end, the designed RNC 

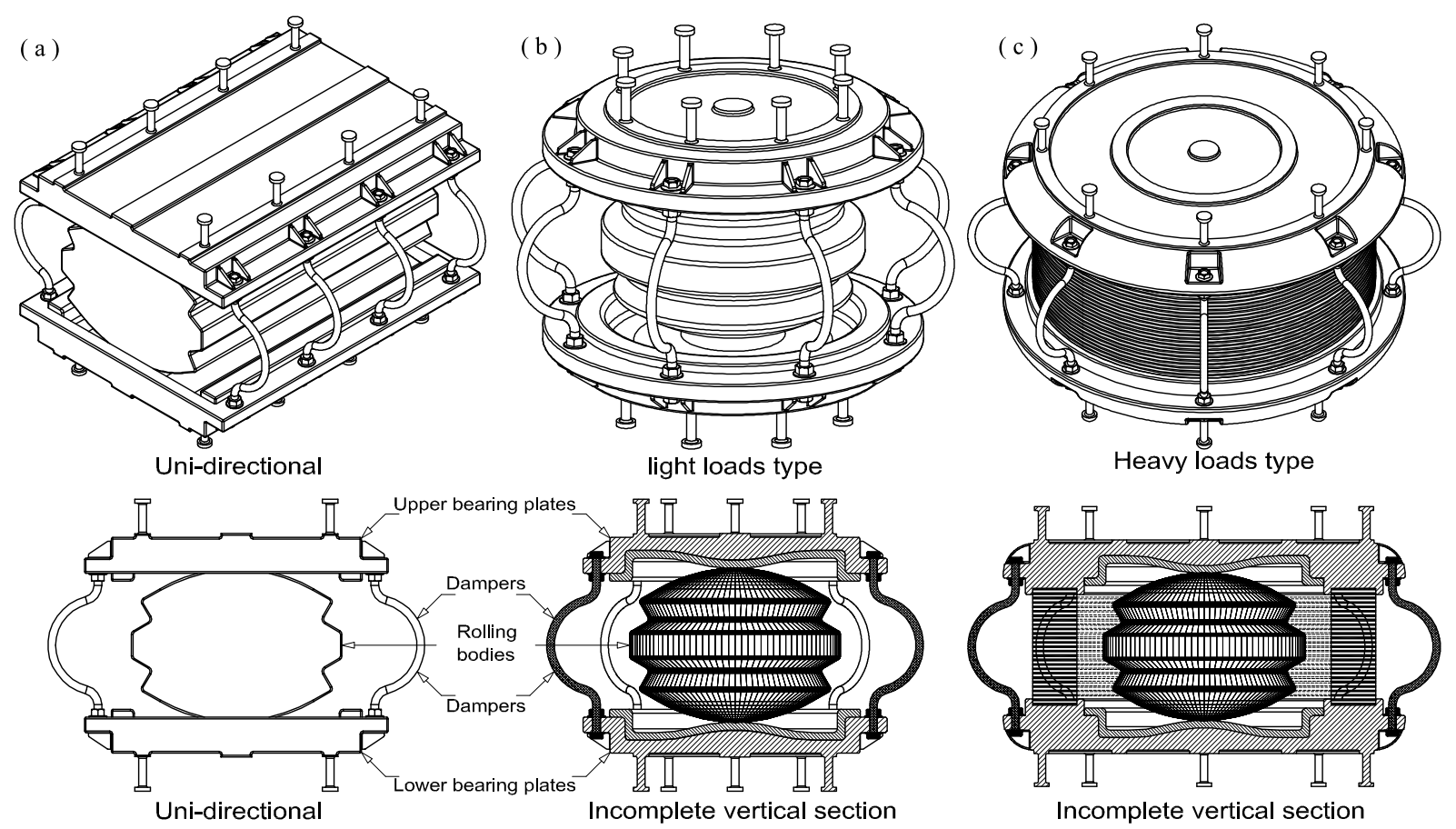

Fig. 1. The available forms of the RNC isolator

TABLE I

MAIN CHARACTERISTICS OF THE NF GROUND MOTIONS USED IN THIS STUDY.

\begin{tabular}{|c|c|c|c|c|c|c|c|c|c|c|c|}
\hline \multirow[b]{2}{*}{ No. } & \multirow{2}{*}{$\begin{array}{l}\text { Earthquake } \\
\text { name }\end{array}$} & \multirow[b]{2}{*}{ Year } & \multirow{2}{*}{$\begin{array}{l}\text { Station } \\
\text { name }\end{array}$} & \multirow{2}{*}{$\begin{array}{l}\text { Magn- } \\
\text { itude }\end{array}$} & \multirow{2}{*}{$\begin{array}{l}\text { Distance } \\
\text { to fault }\end{array}$} & \multicolumn{2}{|c|}{ Peak Accel. ${ }^{a}$} & \multicolumn{2}{|c|}{ Peak Vel. $^{b}$} & \multicolumn{2}{|c|}{ Peak Disp. ${ }^{c}$} \\
\hline & & & & & & PGA & time & PGV & time & PGD & time \\
\hline 1 & Kocaeli, Turkey $60^{\circ}$ & 1999 & Yarimca & 7.51 & $4.80 \mathrm{~km}$ & 0.27 & 13.84 & 67.0 & 13.57 & 58.2 & 14.75 \\
\hline 2 & Imperial Valley $230^{\circ}$ & 1979 & El Centro Ar. \#7 & 6.53 & $0.60 \mathrm{~km}$ & 0.46 & 5.00 & 111.4 & 5.94 & 45.6 & 6.85 \\
\hline 3 & Kobe, Japan $0^{\circ}$ & 1995 & Takarazuka & 6.90 & $0.30 \mathrm{~km}$ & 0.69 & 6.02 & 69.9 & 6.58 & 27.2 & 6.02 \\
\hline 4 & Northridge $18^{\circ}$ & 1994 & Sylmar - Conv. SE & 6.69 & $5.20 \mathrm{~km}$ & 0.83 & 3.51 & 119.8 & 3.44 & 35.1 & 3.02 \\
\hline 5 & San Fernando $164^{\circ}$ & 1971 & Pacoima Dam & 6.61 & $1.80 \mathrm{~km}$ & 1.23 & 7.76 & 114.7 & 3.07 & 36.1 & 7.81 \\
\hline $\begin{array}{l}a \\
b\end{array}$ & $\begin{array}{l}\text { Units: } \mathrm{g}-\mathrm{sec} \\
\text { Units: } \mathrm{cm} / \mathrm{sec}-\end{array}$ & & & & & & & & & & \\
\hline$c$ & Units: $\mathrm{cm}-\mathrm{sec}$ & & & & & & & & & & \\
\hline
\end{tabular}

isolator for this study can support up to $4000.0 \mathrm{kN}$ vertically.

\section{INFLUENCE OF RNC ISOLATOR'S HYSTERETIC DAMPING}

The RNC isolator is provided with a set of triple-curvature metallic yield dampers as shown in Fig. 1, which render the device a hysteretic behavior [11], [10]. Such curvatures are designed to allow for smooth extension and contraction of dampers during motion, provide adequate length of dampers to allow unrestrained rolling motion of the rolling body up to the buffer and to reduce or avoid stress concentrations at bends in order to increase the dampers working life. Three structures were employed in the parametric study performed in this section: the one described in Section III; the same structure but one time is $25 \%$ lighter in weight and the other time is $25 \%$ heavier. This to investigate the influence of the isolated structural weight on bearing displacement and pounding intensity. On the other hand, to investigate the influence of the provided amount of hysteretic damping by the RNC isolator on the bearing displacement and consequently on pounding, four designs of the RNC isolator of the form mentioned in Section III are considered. These isolator designs provide different amount of hysteretic damping that, relatively, ranges from low to high damping and referred to as RNC-1, RNC-2, RNC-3 and RNC-4, respectively. Then, all the RNC-isolated structures were subjected to the five earthquakes of Section II, one at a time, and the resulting bearing displacements as well as the pounding forces are displayed in Fig. 3 . Each earthquake is referred to by its serial number found in the first column from left of Table I. All the response quantities in this section were obtained by simulating the RNC-isolated structures using the structural finite element software SAP2000 [3]. The RNC isolator was modeled by activating the Plastic-Wen hysteretic element, where the buffer mechanism was represented by a nonlinear Gap element. The structure floors were modeled as rigid horizontal diaphragms while the columns were modeled with zero axial deformation and the structural mass is lumped at floor levels. 

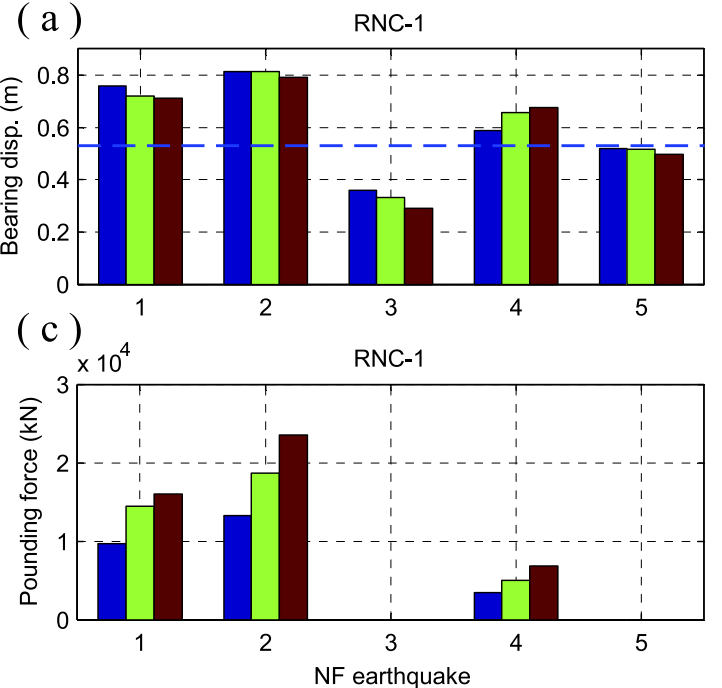

( b )

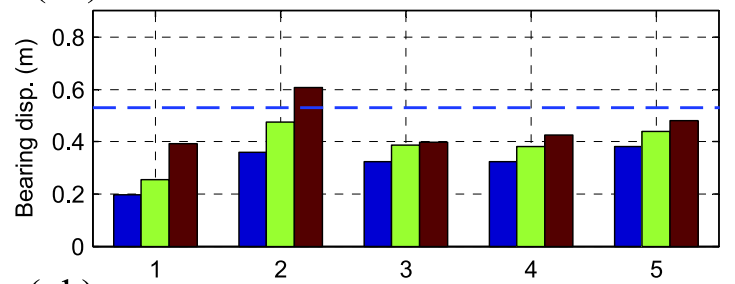

(d)

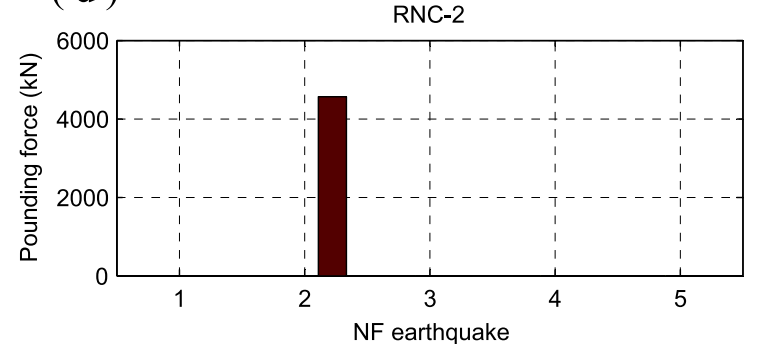

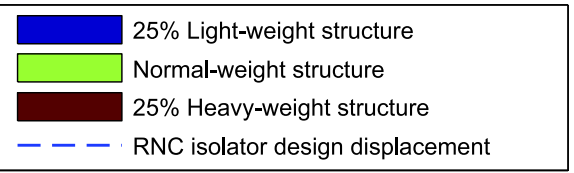

Fig. 3. Effect of structural weight and hysteretic damping on bearing displacement and pounding intensity

The bearing displacements of RNC isolators RNC-1 and RNC-2 are displayed in Figs. 3(a,b), respectively. The corresponding pounding forces are shown in Figs. 3(c,d), respectively. It seems evident that increasing the isolator hysteretic damping decreases the bearing displacement. In some cases, pounding is avoided as the bearing displacement became lower than the design displacement. In other cases, where the bearing displacement is still higher than the design one, increasing damping alleviated the pounding intensity. Fig. 3 also demonstrates that pounding is always more intense in the case of isolated heavy structures, even if they exhibit closer bearing displacements to those of isolated lighter structures. Moreover, the pounding intensity is directly proportional to the amount of extra base displacement beyond the bearing design displacement and the heavier isolated structures are less responsive to increasing the isolator hysteretic damping than lighter isolated structures.

NF ground motions are rich in long period frequencies. This can lead to resonance conditions with seismically isolated structures of long fundamental periods causing undesirable higher bearing displacements. Such resonance seems obvious in this study under the first two earthquakes, particularly, using RNC-1 and RNC-2 isolators. Although the Kocaeli and the Imperial Valley earthquakes have the lowest PGA in Table I, the resulting bearing displacements are the highest, even are higher than those produced by San Fernando earthquake, which has the highest PGA among the used earthquakes. This is mainly attributed to the close structural and loading, dominant, frequencies.
Based on the above results, adding more hysteresis damping to the RNC isolator improves the behavior of the isolated structures in terms of reducing the bearing displacements and the resulting pounding intensity, if there is any. But, practically, this solution should not obstruct the isolator itself to achieve efficient isolation regarding reducing the peak absolute structural accelerations. To investigate that, the corresponding peak absolute structural accelerations of the case study shown in Fig. 3 were obtained and listed in Table II. The performance measure is taken as the reduction percentage of acceleration responses. This percentage (\%) is expressed as:

$$
\%=\frac{\left(\ddot{x}_{\text {fixed-base }}\right)-\left(\ddot{x}_{\text {RNC-isolated }}\right)}{\left(\ddot{x}_{\text {fixed-base }}\right)} \times 100
$$

where $\ddot{x}_{\text {fixed-base }}$ is the peak acceleration of fixed-base structure and $\ddot{x}_{\mathrm{RNC}-\text { isolated }}$ is the peak acceleration of RNCisolated structure. The negative values of $\%$ in Table II indicates the undesired negative effect of pounding on structural accelerations. From this table, the following conclusions could be drawn:

- Increasing the isolator hysteretic damping slightly reduces the peak accelerations of the isolated structure.

- Intense pounding of an isolated structure results in structural accelerations higher than those of its fixed base case. This becomes more obvious in structures with relatively light weight.

- Increasing the isolator hysteretic damping can remarkably attenuate the undesirable increase of the structural accelerations due to pounding.

- The RNC isolator can achieve high levels of structural accelerations reduction, especially under severe ground motions. 
TABLE II

PEAK ABSOLUTE STRUCTURAL ACCELERATIONS USING DIFFERENT RNC ISOLATORS WITH AND WITHOUT BUFFER MECHANISMS. M/SEC ${ }^{2}$ UNITS

\begin{tabular}{|c|c|c|c|c|c|c|c|c|c|c|c|c|c|c|c|c|c|}
\hline \multicolumn{18}{|c|}{$25 \%$ lighter structure } \\
\hline \multirow[b]{2}{*}{$\begin{array}{l}\text { Earthquake } \\
\text { number }\end{array}$} & \multirow[b]{2}{*}{$\begin{array}{l}\text { Fixed } \\
\text { base }\end{array}$} & \multicolumn{4}{|c|}{ RNC-1 } & \multicolumn{4}{|c|}{ RNC-2 } & \multicolumn{4}{|c|}{ RNC-3 } & \multicolumn{4}{|c|}{ RNC-4 } \\
\hline & & $\begin{array}{l}\text { No } \\
\text { buffer }\end{array}$ & $\%$ & $\begin{array}{l}\text { With } \\
\text { buffer }\end{array}$ & $\%$ & $\begin{array}{l}\text { No } \\
\text { buffer }\end{array}$ & $\%$ & $\begin{array}{l}\text { With } \\
\text { buffer }\end{array}$ & $\%$ & $\begin{array}{l}\text { No } \\
\text { buffer }\end{array}$ & $\%$ & $\begin{array}{l}\text { With } \\
\text { buffer }\end{array}$ & $\%$ & $\begin{array}{l}\text { No } \\
\text { buffer }\end{array}$ & $\%$ & $\begin{array}{l}\text { With } \\
\text { buffer }\end{array}$ & $\%$ \\
\hline 1 & 7.35 & 0.890 & $88 \%$ & 15.883 & $-116 \%$ & 1.095 & $85 \%$ & 1.095 & $85 \%$ & 1.487 & $80 \%$ & 1.487 & $80 \%$ & 1.946 & $74 \%$ & 1.946 & $74 \%$ \\
\hline 2 & 9.50 & 1.129 & $88 \%$ & 22.698 & $-139 \%$ & 1.534 & $84 \%$ & 11.442 & $-20 \%$ & 1.790 & $81 \%$ & 1.790 & $81 \%$ & 2.351 & $75 \%$ & 2.351 & $75 \%$ \\
\hline 3 & 19.91 & 1.028 & $95 \%$ & 1.028 & $95 \%$ & 1.684 & $92 \%$ & 1.684 & $92 \%$ & 1.912 & $90 \%$ & 1.912 & $90 \%$ & 2.334 & $88 \%$ & 2.334 & $88 \%$ \\
\hline 4 & 28.77 & 0.711 & $98 \%$ & 5.028 & $83 \%$ & 1.282 & $96 \%$ & 1.282 & $96 \%$ & 1.590 & $94 \%$ & 1.590 & $94 \%$ & 2.078 & $93 \%$ & 2.078 & $93 \%$ \\
\hline 5 & 53.01 & 1.092 & $98 \%$ & 1.092 & $98 \%$ & 1.693 & $97 \%$ & 1.693 & $97 \%$ & 1.808 & $97 \%$ & 1.808 & $97 \%$ & 2.246 & $96 \%$ & 2.246 & $96 \%$ \\
\hline \multicolumn{18}{|c|}{ Normal weight structure } \\
\hline 1 & 11.35 & 0.616 & $95 \%$ & 14.538 & $-28 \%$ & 0.988 & $91 \%$ & 4.209 & $63 \%$ & 1.176 & $90 \%$ & 1.176 & $90 \%$ & 1.508 & $87 \%$ & 1.508 & $87 \%$ \\
\hline 2 & 15.15 & 0.924 & $94 \%$ & 22.809 & $-51 \%$ & 1.329 & $91 \%$ & 16.814 & $-11 \%$ & 1.495 & $90 \%$ & 8.783 & $42 \%$ & 1.745 & $88 \%$ & 1.745 & $88 \%$ \\
\hline 3 & 24.66 & 1.064 & $96 \%$ & 1.064 & $96 \%$ & 1.498 & $94 \%$ & 1.498 & $94 \%$ & 1.521 & $94 \%$ & 1.521 & $94 \%$ & 1.741 & $93 \%$ & 1.741 & $93 \%$ \\
\hline 4 & 21.55 & 0.654 & $97 \%$ & 9.104 & $58 \%$ & 0.996 & $95 \%$ & 0.996 & $95 \%$ & 1.285 & $94 \%$ & 1.285 & $94 \%$ & 1.664 & $92 \%$ & 1.664 & $92 \%$ \\
\hline 5 & 44.26 & 0.728 & $98 \%$ & 0.728 & $98 \%$ & 1.265 & $97 \%$ & 1.265 & $97 \%$ & 1.530 & $97 \%$ & 1.530 & $97 \%$ & 2.000 & $95 \%$ & 2.000 & $95 \%$ \\
\hline \multicolumn{18}{|c|}{$25 \%$ heavier structure } \\
\hline 1 & 10.51 & 0.486 & $95 \%$ & 14.652 & $-39 \%$ & 0.847 & $92 \%$ & 10.994 & $-5 \%$ & 1.057 & $90 \%$ & 3.067 & $71 \%$ & 1.287 & $88 \%$ & 1.287 & $88 \%$ \\
\hline 2 & 13.32 & 0.746 & $94 \%$ & 22.773 & $-71 \%$ & 1.206 & $91 \%$ & 19.280 & $-45 \%$ & 1.355 & $90 \%$ & 12.683 & $5 \%$ & 1.525 & $89 \%$ & 7.324 & $45 \%$ \\
\hline 3 & 27.89 & 0.696 & $98 \%$ & 0.696 & $98 \%$ & 1.207 & $96 \%$ & 1.207 & $96 \%$ & 1.288 & $95 \%$ & 1.288 & $95 \%$ & 1.525 & $95 \%$ & 1.525 & $95 \%$ \\
\hline 4 & 19.56 & 0.566 & $97 \%$ & 10.414 & $47 \%$ & 0.958 & $95 \%$ & 1.769 & $91 \%$ & 1.104 & $94 \%$ & 1.104 & $94 \%$ & 1.375 & $93 \%$ & 1.375 & $93 \%$ \\
\hline 5 & 34.22 & 0.680 & $98 \%$ & 0.680 & $98 \%$ & 1.154 & $97 \%$ & 3.445 & $90 \%$ & 1.230 & $96 \%$ & 1.230 & $96 \%$ & 1.639 & $95 \%$ & 1.639 & $95 \%$ \\
\hline
\end{tabular}

- Where there is no pounding, isolation of light-weight structures is less efficient under low-intensity earthquakes compared to heavier structures under the same earthquakes. This isolation efficiency becomes higher under stronger earthquakes showing similar behavior to that of heavier structures under such strong earthquakes.

\section{HYBRID RNC-ISOLATION}

In this section, the RNC isolator is allowed to behave as a purely passive isolation system, with hysteretic damping, within a particular range of the design bearing displacement as denoted in Fig. 2 by $\Delta_{\mathrm{p}}$. Then active control force is applied over $\Delta_{\mathrm{h}}$, after which pounding will take place. The purpose of active control is to reduce the bearing displacement to avoid or even reduce pounding intensity, see Fig. 2.

\section{A. Modeling of RNC-isolated structure with active damping}

The equations of motion of an $N$-story linear shear type superstructure subjected to earthquake excitation is written in the matrix form as:

$$
\mathbf{M}_{\mathrm{s}} \ddot{\mathbf{x}}_{\mathrm{s}}+\mathbf{C}_{\mathrm{s}} \dot{\mathbf{x}}_{\mathrm{s}}+\mathbf{K}_{\mathrm{s}} \mathbf{x}_{\mathrm{s}}=-\mathbf{M}_{\mathrm{s}}\{\mathbf{1}\}\left(\ddot{x}_{\mathrm{b}}+\ddot{x}_{\mathrm{g}}\right)
$$

where $\mathbf{M}_{\mathrm{s}}, \mathbf{K}_{\mathrm{s}}$, and $\mathbf{C}_{\mathrm{s}}$ are the $N \times N$ mass, stiffness and damping matrices of the superstructure, respectively; $\mathbf{x}_{\mathrm{S}}=\left\{x_{1}, x_{2}, \ldots, x_{N}\right\}^{T}$ is the relative displacement vector of the superstructure; $\dot{\mathrm{x}}_{\mathrm{S}}$ and $\ddot{\mathrm{x}}_{\mathrm{S}}$ are the relative velocity and acceleration vectors, respectively; $x_{j}(j=1,2, \ldots, N)$ is the lateral displacement of the $j$ th floor relative to the base mass; $\{\mathbf{1}\}=\{1,1,1, \ldots, 1\}^{T}$ is the influence coefficient vector; $\ddot{x}_{\mathrm{b}}$ is the relative acceleration of the base mass; and $\ddot{x}_{\mathrm{g}}$ is the earthquake ground acceleration.
The governing equation of motion of the base mass is given by

$$
m_{\mathrm{b}} \ddot{x}_{\mathrm{b}}+\eta F_{\mathrm{b}}-c_{1} \dot{x}_{1}-k_{1} x_{1}=-m_{\mathrm{b}} \ddot{x}_{\mathrm{g}}+u
$$

where $m_{\mathrm{b}}$ is the suspended mass of the base raft; $c_{1}$ and $k_{1}$ are the damping and stiffness of the first story, respectively; $\eta$ is the total number of RNC isolators; $F_{\mathrm{b}}$ is the restoring force transmitted to the suspended base mass by a single $\mathrm{RNC}$ isolator and $u$ is the active control force.

The RNC isolator restoring force is represented by the standard Bouc-Wen model [24], [8] as:

$$
\begin{aligned}
F_{\mathrm{b}}(t) & =\alpha k x(t)+(1-\alpha) D_{\mathrm{y}} k z(t) \\
\dot{z} & =D_{\mathrm{y}}^{-1}\left(A \dot{x}-\beta|\dot{x}||z|^{n-1} z-\gamma \dot{x}|z|^{n}\right)
\end{aligned}
$$

where $x$ is the displacement, $z$ is an auxiliary variable, $F_{\mathrm{b}}$ is the isolator restoring force, $\alpha k x$ is the elastic force component, $\dot{z}$ denotes the time derivative, $n>1$ is a parameter that governs the smoothness of the transition from elastic to plastic response, $D_{\mathrm{y}}>0$ is the yield constant displacement, $k>0$ and $0<\alpha<1$ represents the post to pre-yielding stiffness ratio $\left(k_{\mathrm{b}} / k_{\mathrm{e}}\right)$, while $A, \beta$ and $\gamma$ are non-dimensional parameters that govern the shape and size of the hysteresis loop.

\section{B. Controler design}

Two active control laws are considered in this study. The first is a simple static discontinuous active bang-bang type control, which was developed using only the measurement of velocity of the suspended base floor of an isolated structure as a feedback information [21]. The control force is expressed as:

$$
u=-\rho \operatorname{sign}\left(\dot{x}_{\mathrm{b}}\right)
$$


where $\rho$ is a design parameter and $\dot{x}_{\mathrm{b}}$ is the velocity of the suspended base floor of the isolated structure.

The second controller is based on using a passive static hyperbolic function depending only on the base floor velocity [20]. This function ensures energy dissipation capability with always bounded control force. The control law is:

$$
u=-\rho \operatorname{sech}\left(\frac{\dot{x}_{\mathrm{b}}}{a}\right) \tanh \left(\frac{\dot{x}_{\mathrm{b}}}{a}\right)
$$

where $\rho>0$ and $a>0$ are design parameters.

\section{Parametric study}

Using the RNC isolator, the expected pounding will take place within the isolator components when the displacement of the suspended base floor reaches the end of the bearing design displacement with considerable amount of kinetic energy. The undesirable pounding effects are then reflected first on the suspended base floor, as the first structural part connected to the RNC isolator, then spread through the isolated structure. Active damping is studied in this section as a possible mean of reducing the base floor velocity to reduce its kinetic energy and consequently to alleviate pounding intensity. Therefore, the value of controlled base velocity is considered as a measure of both the pounding intensity and the efficiency of control laws in this section.

The three isolated structures of Section IV were studied in this section along with only the RNC-1 isolator under earthquake 1. Active control force was applied over the whole range of the bearing design displacement, that is [1 cm $-53 \mathrm{~cm}]$, with an increment of $1 \mathrm{~cm}$. This is to check weather there is an optimum distance for applying the control force or not before the RNC isolator reaches the end of its design displacement. The resulting bearing displacements are plotted in Fig. 5. This figure shows that the active control can reduce the bearing displacement especially when applied at smaller values of $\Delta_{p}$ and the heavier isolated structure is less responsive to active control force than lighter ones.

To investigate the influence of combining active control with the purely passive RNC isolator to reduces bearing displacement on the isolation efficiency, different values of active control force, using the first control law (6), were applied at three different values of $\Delta_{\mathrm{p}} / \Delta$ of $20 \%, 50 \%$ and $80 \%$. The corresponding response quantities are found and listed in Table III under earthquake 1 using the three example structures. The main conclusion that can be drawn from that table is that the hybrid seismic isolation is more effective if the active control forces are applied at smaller values of the ratio $\Delta_{\mathrm{p}} / \Delta$ to avoid pounding. The resulting structural absolute accelerations are higher than those of purely passively isolated structures, which means that hybrid

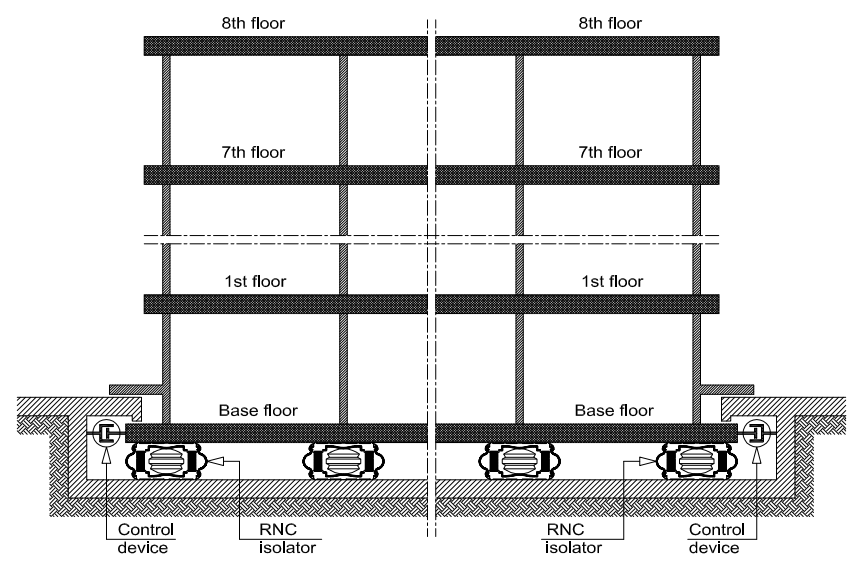

Fig. 4. Idealized RNC-isolated structural model with control devices

isolation adds more rigidity to the isolated structure. This decreases the structure-ground decoupling and consequently leads to less effective isolation. Moreover, the lighter the isolated structure the lower the control force and the more efficient the hybrid isolation. However, in all cases, the hybrid isolation provides higher structural accelerations than the purely passive isolation.

\section{CONCLUSIONS}

In this paper, a recently proposed isolation system with hysteretic damping was used to study pounding mitigation under near-fault earthquakes. This isolation system is referred to as roll in cage (RNC) isolator. It has an integrated buffer mechanism to prevent excessive bearing displacements under strong seismic excitations. Since the pounding depends on the bearing displacement and the isolated base velocity, the influence of increasing the isolator's hysteretic damping and applying active damping on the bearing displacement and the base floor velocity, respectively, was studied with the aim of pounding mitigation or even its avoidance. Based on the performed study, the following conclusions were drawn:

1) Increasing the isolator hysteretic damping decreases the bearing displacement and consequently alleviates the pounding intensity.

2) The heavy-weight isolated structures are less responsive to increasing the isolator hysteretic damping than the light-weight ones.

3) Pounding is always more intense in the case of isolated heavy structures, even if they exhibit closer bearing displacements to those of isolated lighter structures.

4) Pounding intensity is directly proportional to the amount of extra base displacement beyond the bearing design displacement.

5) Increasing the isolator hysteretic damping slightly reduces the peak accelerations of the isolated structure.

6) Intense pounding of an isolated structure results in structural accelerations higher than those of its fixed base case. This becomes more obvious in structures with relatively light weight. 

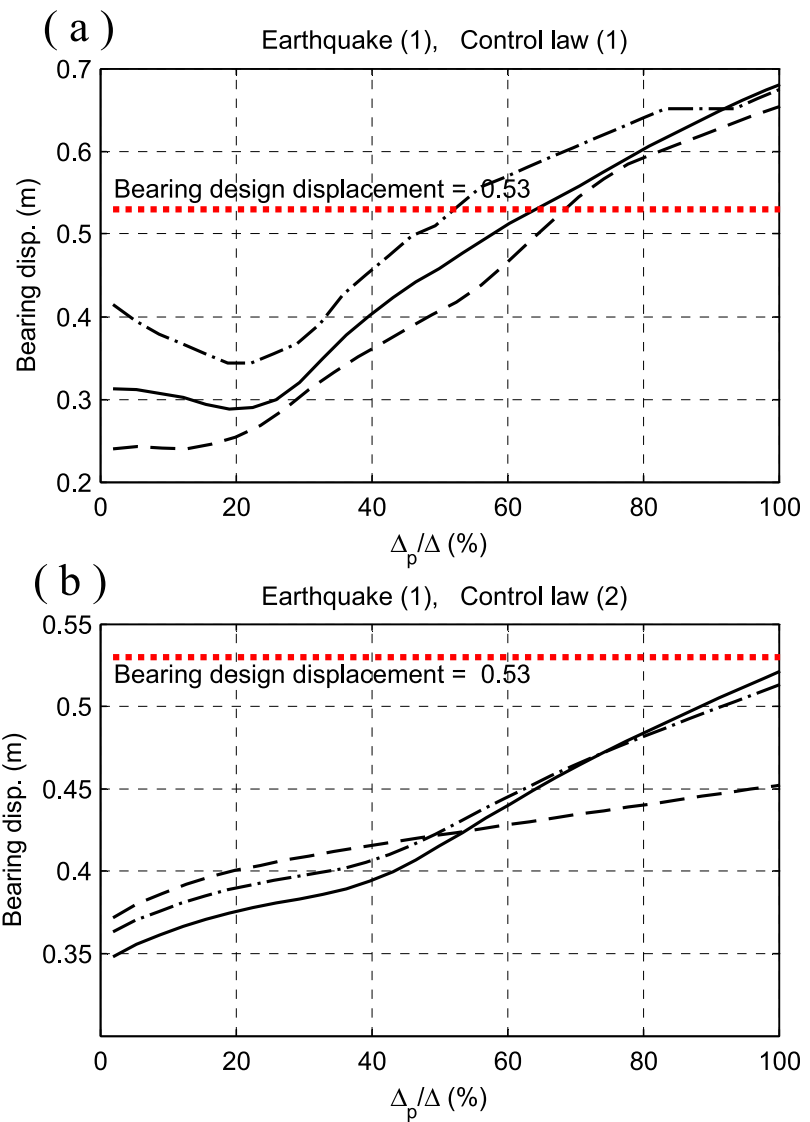

$$
\begin{aligned}
& - \text { Normal-weigt structure } \\
& ---25 \% \text { light-weigt structure } \\
& -\cdot-\cdot-25 \% \text { heavy-weigt structure }
\end{aligned}
$$

Fig. 5. Peak actively controlled bearing displacements under earthquakes 1 using control laws 1 and 2

7) Increasing the isolator hysteretic damping can remarkably attenuate the undesirable increase of the structural accelerations due to pounding.

8) The RNC isolator can achieve high levels of structural accelerations reduction, especially under severe ground motions.

9) Where there is no pounding, isolation of light-weight structures is less efficient under low-intensity earthquakes compared to heavier structures under the same earthquakes. This isolation efficiency becomes higher under stronger earthquakes showing similar behavior to that of heavier structures under such strong earthquakes.

10) Hybrid isolation can reduce the bearing displacement to avoid pounding, particularly when the active control forces are applied at smaller values of the ratio $\Delta_{p} / \Delta$.

11) Lighter isolated structures are more responsive to hybrid isolation using less control forces compared to the isolated heavier structures.

12) Hybrid control renders the isolation system more rigidity, which leads to less efficient isolation in terms of higher structural peak absolute accelerations compared to purely passive isolation system.

\section{REFERENCES}

\section{REFERENCES}

[1] Uniform Building Code. International Conference of Building Officials. California, Whittier, 1997.

[2] AASHTO LRFD Bridge Design Specifications, SI Units, Third Edition. American Association of State Highway and Transportation Officials, 2005, Interim Revisions.

[3] SAP2000 release 15.0 documentation. Computers and Structures, Inc., 1995 University Ave, Berkeley CA 94704, 2011.

[4] V.K. Agarwal, J.M. Niedzwecki, and J.W. van de Lindt. Earthquake induced pounding in friction varying base isolated buildings. Engineering Structures, 29(11):2825-2832, 2007.

[5] A. Barbat, J. Rodellar, E. Ryan, and N. Molinares. Active control of nonlinear base-isolated buildings. Engineering Mechanics (ASCE), 121(6):676-684, 1995.

[6] S.J. Dyke, B.F. Spencer, M.K. Sain, and J.S. Carlson. Modeling and control of magnetorheological dampers for seismic response reduction. Smart Materials and Structures, 5(5):565-575, 1996.

[7] J. Inaudi, F. Lopez-Almansa, J.M. Kelly, and J. Rodellar. Predictive control of base isolated structures. Earthquake Engineering and Structural Dynamics, 21(6):471-482, 1992.

[8] M. Ismail, F. Ikhouane, and J. Rodellar. The hysteresis Bouc-Wen model, a survey. Journal of Archives of Computational Methods in Engineering, 16:161-188, 2009.

[9] M. Ismail, J. Rodellar, and F. Ikhouane. A Seismic Isolation System for Supported Objects. Spanish Patent No. P200802043, Spanish Office of Patents and Marks, 2008.

[10] M. Ismail, J. Rodellar, and F. Ikhouane. A novel isolation bearing for light- to moderate-weight structures. Journal of Structural Control and Health Monitoring, 2009. DOI: 10.1002/stc.421.

[11] M. Ismail, J. Rodellar, and F. Ikhouane. An innovative isolation device for aseismic design. Journal of Engineering Structures, 32:1168-1183, 2010.

[12] R.S. Jangid and J.M. Kelly. Base isolation for near-fault motions. Earthquake Engineering and Structural Dynamics, 30:691-707, 2001.

[13] P. Komodromos. Simulation of the earthquake-induced pounding of seismically isolated buildings. Computers \& Structures, 86:618-626, 2008

[14] P. Komodromos, P.C. Polycarpou, L. Papaloizou, and M.C. Phocas. Response of seismically isolated buildings considering poundings. Earthquake Engineering and Structural Dynamics, 36:1605-1622, 2007.

[15] N. Makris and C.J. Black. Evaluation of peak ground velocity as a good intensity measure for near-source ground motions. Engineering Mechanics (ASCE), 130(9):1032-1044, 2004.

[16] P.K. Malhotra. Dynamics of seismic impacts in base-isolated buildings. Earthquake Engineering and Structural Dynamics, 26:797-813, 1997.

[17] V.A. Matsagar and R.S. Jangid. Seismic response of base-isolated structures during impact with adjacent structures. Engineering Structures, 25:1311-1323, 2003.

[18] D. Murat and B. Srikanth. Equivalent linear analysis of seismicisolated bridges subjected to near-fault ground motions with forward rupture directivity effect. Engineering Structures, 29:21-32, 2007.

[19] P.C. Polycarpou and P. Komodromos. Earthquake-induced poundings of a seismically isolated building with adjacent structures. Engineering Structures, 32:1937-1951, 2010.

[20] F. Pozo, L. Acho, and J. Rodellar. Hyperbolic control for vibration mitigation of a base-isolated benchmark structure. Structural Control and Health Monitoring, 16:766-783, 2009.

[21] F. Pozo, P.M. Montserrat, J. Rodellar, and L. Acho. Robust active control of hysteretic base-isolated structures: Application to the benchmark smart base-isolated building. Structural Control and Health Monitoring, 15:720-736, 2008

[22] J.C. Ramallo, E.A. Johnson, and B.F. Spencer. Smart base isolation systems. Journal of Engineering Mechanics, 128:1088-1100, 2002.

[23] H.C. Tsai. Dynamic analysis of base-isolated shear beams bumping against stops. Earthquake Engineering and Structural Dynamics, 26:515-528, 1997.

[24] Y.K. Wen. Method for random vibration of hysteretic systems. Journal of the Engineering Mechanics Division, 102(EM2):246-263, April 1976.

[25] J.N. Yang and A.K. Agrawal. Semi-active hybrid control systems for nonlinear buildings against near-field earthquakes. Engineering Structures, 24(3):271-280, 2002. 


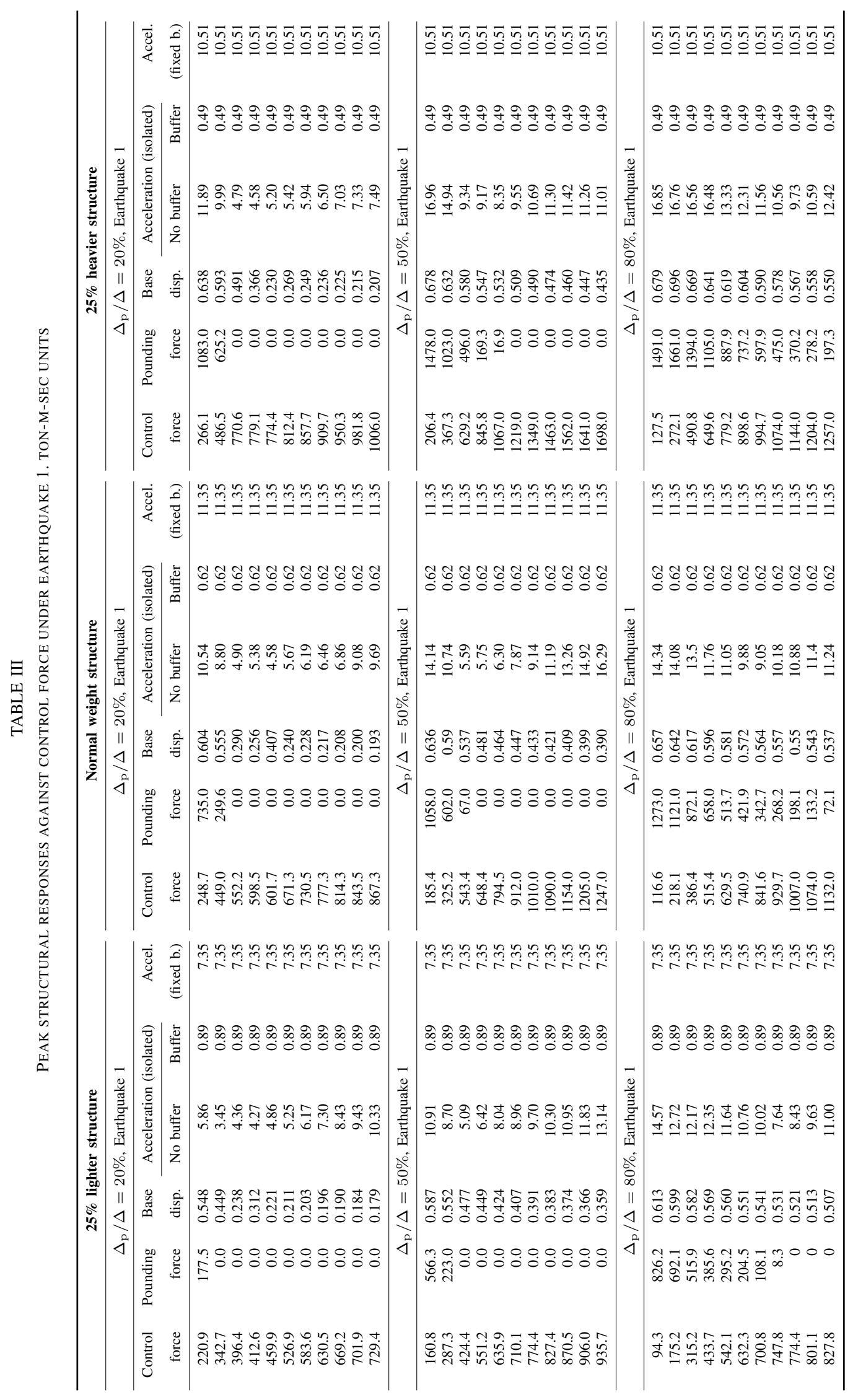

